\title{
Öğrencilerin Finans Dersi Alma Durumunun Finansal Okur Yazarlık Seviyesine Etkisi: Bir Nazilli Örneği
}

\author{
DOI: $10.26466 /$ opus. 553171 \\ * \\ Umut Tolga Gümüș \\ * Dr. Öğr. Üyesi , Adnan Menderes Ümiversitesi, Nazilli İ̈BF, Aydın/Türkiye \\ E-Posta: ugumus@adu.edu.tr \\ ORCID: 0000-0001-7363-8660 \\ **Yl. Öğrencisi, Adnan Menderes Üniversitesi, Sosyal Bilimler Enstitüsü, Aydın /Tükiye \\ E-Posta: kutaypailer@gmail.com \\ ORCID: $\underline{0000-0003-4145-8870}$
}

Öz

Finansal okuryazarlık düzeyi, eğitim düzeylerine göre farklılaşmaktadır. Hiç finans dersi almamış bireylerle teorik finans dersi almış bireylerin finansal okur yazarlık düzeylerinin eşit seviyede olmaması beklenmekteir. Bu araştırmanın amacı, finans eğitimini başarıyla tamamlamış öğrenciler ile finans eğitimi almamış öğrenciler arasındaki finansal okur yazarlık bilgi, algı ve davranışlarının farklılıkların ölçmektir.Araştırmamız kapsamında, Aydın Adnan Menderes Üniversitesi Nazilli İktisadi ve İdari Bilimler Fakültesi İ̧sletme bölümü 1. ve 4. sinıfta okuyan 268 öğrenciye, 5'li likert yöntemi ile anket çalışması uygulanmıştır. Anket formu, demografik sorularının yanı sıra finansal okur yazarlık bileşenlerinden finansal bilgi, algı ve davranış olmak üzere 3 ana gruba ayrılmıştır. Çalışmada 3 demografik soru üzerinden finansal okur yazarlık analizi yapılmıştır. Finansal bilgi sorularının analizi için ChiSquare, finansal algı ve finansal davranış sorularının analizi için Bă̆ımsız Örneklem T-Test'i uygulanmıştır. Cinsiyet ve çalışma durumu sorularıyla yapılan analizlerde anlamlı bir sonuca ulaşılamamış, finans dersi alma durumuna göre yapılan analizlerde ise anlamlı bir farklllık elde edilmiştir. Ayrica finans dersi alma durumunda en bariz farklllık faiz, risk-getiri ilişkisi, finansal araçlar ve finansal piyasalar konularında ortaya çıkmıştır.

Anahtar Kelimeler: Finansal okur yazarlık, Finansal bilgi, Finans eğitimi 


\title{
The Effect of Students Finance Learning Situation on the Level of Financial Literacy: A Case Of Nazilli
}

\begin{abstract}
The level of financial literacy differs according to the level of education. It is expected that financial literacy levels of individuals who have never taken finance courses and individuals who have taken theoretical finance courses are not equal. The aim of this study is to measure the differences in financial literacy knowledge, perception and behavior between the students who have successfully completed finance education and those who have not received finance education. , 5-point Likert method was applied to the survey. In addition to demographic questions, the questionnaire was divided into three main groups: financial knowledge, perception and behavior. In this study, financial literacy analysis was conducted on 3 demographic questions. Chi-Square was used for the analysis of financial information questions and Independent Sample T-Test was used for the analysis of financial perception and financial behavior questions. A meaningful result was not reached in the analyzes made with the questions of gender and working status, and a significant difference was obtained in the analyzes made according to the status of taking finance courses. In addition, the most significant difference in taking finance courses emerged in interest, risk-return relationship, financial instruments and financial markets.
\end{abstract}

Keywords: Financial literacy, Financial information, Financial education 


\section{Giriş}

Finansal okuryazarlık, sadece finansal araçlarla finansal piyasalarda gerçekleştirilen işlemleri kapsamamaktadır. Bireyler günlük yaşamlarında karşılaştıkları sorunlarını çözerken de finansal okuryazarlık bilgilerinden faydalanır. Gittikçe komplike bir hal alan piyasaları doğru yorumlamak finans çalışanları için bile oldukça zor iken, finansal okuryazarlık konusunda eksik bilgiye sahip bireylerin piyasaları doğru yorumlayabilmeleri her geçen gün daha zor bir hal almaktadır. Çünkü finansal piyasalar gün geçtikçe daha karmaşık ve riskli bir yapıya ulaşmıştır.

Finansal piyasaların en önemli parçası olarak bireyler ve bireylerin yapmış oldukları harcama, tasarruf, yatırım gibi davranışları piyasalar için yadsınamaz bir öneme sahiptir. Bir bütün olarak ele alındığında bireylerin barınma ve gıda gibi temel yaşamihtiyaçlarını karşılarken yapmış oldukları hareketleri bile piyasa içerisinde bir etkiye sebep olmaktadır. Gerçekleştirilen tüm faaliyetler, piyasadan talep edilmiş olunan ihtiyaçlar piyasaların arz talep dengelerini oluşturmalarında önemli bir etkiye sahiptir. Toplumun ihtiyaçları doğrultusunda yaptıkları hareketler sonucunda meydana gelen bu etkiler piyasaları olumlu ya da olumsuz yönde etkileyebilmektedir. Bu durumda önemli olan piyasalarda meydana gelen olumlu ya da olumsuz yöndeki değişimlerin gerçek mi yoksa spekülatif hareketlenmelerden mi kaynaklandığının bireyler tarafından tespit edilmesi ve o yönde hamle yapılmasıdır. Ancak bireylerin doğru hamlelerde bulunabilmeleri finansal konularda bilgi sahibi olmaları ile mümkündür.

Ülkemize açısından bakıldığında bireyler üniversite eğitimine başladıkları dönemde ailelerinden ayrı bir harcama planı oluşturmaya ihtiyaç duydukları için ilk defa bu dönemde gelir harcama dengesini oluşturmaya çalışırlar. Harcama dengesini kurmakta zorlanan bireyler maddi olarak zor durumlara düşerler ve bu durumda insanlarda gelecek kaygısına sebep olmaktadır. Gelecek kaygısı sadece finansal özgürlügünü yeni kazanmış bireyler için değil tüm toplum için etkili olan bir durumdur. Özellikle yaşanan küresel kriz dönemlerinde gelecek kaygısı tüm toplumu daha derinden etkisi altına almaktadır. Yaşanan küresel krizlerde insanlar kendilerini aşırı borçlu ve finansal olarak yetersiz bir 
durum içersinde bulurlar. Kötü finansal durumlarını düzeltmek, bilinçli yatırımlar ve harcamalar yapabilmek için bireylerin finansal okuryazarlık eğitimine ihtiyacı vardır. Bu eğitimlerin verilmesinde devlet yönetimleri, okullar, kurum ve kuruluşlar önemli bir rol oynarlar. Bu sebeple bu çalışma Aydın Adnan Menderes Üniversitesi İktisadi İdari Bilimler Fakültesi İşletme bölümü öğrencilerinin finansal okuryazarlık bilgi, alg1 ve davranışları üzerinde finans eğitimi alıp almamalarının öğrenciler arasındaki oluşturduğu farkı tespit etmek amacıyla gerçekleştirilmiştir.

Çalışmamızın ikinci bölümünde finansal okuryazarlık üzerine yapılmış çalışmalar kısaca özetlenmiştir. Üçüncü bölümde finansal okuryazarlık kavramının tanımı, amacl, önemi ve bileşenleri irdelenmiştir. Dördüncü bölümde araştırmamızın yöntemi, önemi ve kapsamına dair bilgiler verilmiştir. Beşinci bölümde araştırmamızın matematiksel verileri tablolar yardımıyla aktarılmıştır. Altıncı bölümde araştırma sonuçları tartışılmış ve önerilerde bulunulmuştur.

\section{Literatür Taraması}

Çalışmamızın bu bölümünde son yıllarda finansal okuryazarlıkla ilgili yapılmış çalışmalara kısaca değinilmiştir. Bu çalışmalarda çoğunlukla öğrenciler üzerine anket yöntemi uygulanarak sonuçlar elde edilmiştir. Bu çalışmalar kısaca aşağıdaki tabloda değinilmiştir.

\section{Tablo 1. Literatür taraması}

\begin{tabular}{|c|c|}
\hline $\begin{array}{l}\text { Er ve } \\
\text { Çetintaş (2018) }\end{array}$ & $\begin{array}{l}\text { Bu çalışmada iş̧̧ilerin finansal okuryazarlık düzeyleri araştırılmıştır. İşçilere } \\
\text { yapıllan anket sonucunda işçilerin finansal okuryazarlık düzeylerinin ülke ortala- } \\
\text { masının üzerinde olduğu tespit edilmiştir. }\end{array}$ \\
\hline $\begin{array}{l}\text { Barmakı ve } \\
\text { Şener (2017) }\end{array}$ & $\begin{array}{l}\text { Bu çalışmanın amacı Hacettepe Üniversitesi öğrencilerinin finansal okuryazarlık } \\
\text { düzeylerini belirlemektedir. Çalısma sonucunda öğrencilerin \%53.62'sinin soru- } \\
\text { lara doğru cevap verdikleri tespit edilmiştir. Dolayısıyla bu durumda finansal } \\
\text { okuryazarlık düzeyleri orta seviyededir. }\end{array}$ \\
\hline $\begin{array}{l}\text { Danışman, } \\
\text { Vd.(2016) }\end{array}$ & $\begin{array}{l}\text { Finansal kararlar hakkında geniş bir yelpazeye sahip olduğu düşünülen İktisadi } \\
\text { ve İdari Bilimler Fakültesi ögrencilerinin finansal okuryazarlık konusunda sahip } \\
\text { oldukları bilgi düzeyinin belirlenmesi adına yapılan anket çalışmasında elde } \\
\text { edilen sonuç öğrencilerin temel düzeyde finansal okuryazar oldukları an- } \\
\text { laşılmışır. }\end{array}$ \\
\hline Sarıgül (2015) & $\begin{array}{l}\text { Bu araştırmada üniversite öğrencilerinin finansal tutum ve davranışları ölçül- } \\
\text { müştür. Anket sonuçları üzerine açıklayııı faktör analizleri yapılmştır. Faktör } \\
\text { analizi toplam büyüklüğün \% 49,24'ünü açıklayan dört faktör elde edilmiștir. }\end{array}$ \\
\hline
\end{tabular}




\begin{tabular}{|c|c|}
\hline Coşkun (2016) & $\begin{array}{l}\text { Bu çalışma Manisa Celal Bayar Üniversitesi ön lisans öğrencilerinin finansal } \\
\text { okuryazarlık algılarının finansal davranışlarını nasıl etkilediğini tespit amacıyla } \\
\text { yapılmıştır. Elde edilen sonuçlar öğrencilerin finansal ürünler hakkında bilgi sa- } \\
\text { hibi olduklarını göstermektedir. }\end{array}$ \\
\hline Er vd. (2014) & $\begin{array}{l}\text { Lisans eğitim program içeriklerinin finansal okuryazarlığa etkisi araştırılmıştır. } \\
\text { Sonuç olarak ise öğrencilerin \%31.7'sinin yüksek \%30,1'inin orta \%16'sının ise } \\
\text { düşük finansal okuryazarlığa egemen oldukları tespit edilmiştir. }\end{array}$ \\
\hline Kılıç Vd.(2015) & $\begin{array}{l}\text { Gaziantep Üniversitesi öğrencilerine uygulanan bu çalışmada öğrencilerin fi- } \\
\text { nansal okuryazarlık düzeylerinin çeşitli demografik özellikleri bakımından } \\
\text { incelenmiştir. Çalışmanın sonunda ulaşılan sonuca göre finansal okurya- } \\
\text { zarlıktaki genel başarı oranı \% } 48 \text { olarak bulunmuştur. Kadın öğrencilerin bu ko- } \\
\text { nudaki bilgi düzeyi erkek öğrencilere göre daha düşük çıkmışıtır. }\end{array}$ \\
\hline $\begin{array}{l}\text { Demirkol ve } \\
\text { Erduru (2017) }\end{array}$ & $\begin{array}{l}\text { Harran Üniversitesi İktisadi ve İdari Bilimler Fakültesi 4.sınıf öğrencilerinin fi- } \\
\text { nansal okuryazarlık düzeylerini tespit etmek amacıyla yapılan bu çalışmada } \\
\text { öğrencilerin finansal okuryazarlık düzeylerinin yeterli düzeyde olmadığı ve bazı } \\
\text { demografik değişkenlere göre öğrencilerin finansal okuryazarlık düzeylerinde } \\
\text { farklılıklar olduğu tespit edilmiştir. }\end{array}$ \\
\hline $\begin{array}{l}\text { Tuna Ve Ulu } \\
\text { (2016) }\end{array}$ & $\begin{array}{l}\text { Bu araştırmada Sakarya Üniversitesi öğrencilerinin finansal bilgi düzeyinin } \\
\text { öğrenim görülen sınıf ya da öğrenim türüne göre nasıl farklllık gösterdiği } \\
\text { incelenmiştir. Elde edilen sonuçlara göre verilen faktörler finansal bilgi düzeyi } \\
\text { açısından önemli farklllıklara sahiptirler. }\end{array}$ \\
\hline $\begin{array}{l}\text { Şamiloğlu } \\
\text { vd.(2016) }\end{array}$ & $\begin{array}{l}\text { Erciyes Üniversite'sinde yapılan bu anket çalışması ile öğrencilerin finansal } \\
\text { okuryazarlık davranışlarının analizi yapılmıstır. Araştırma anketinde işletme } \\
\text { öğrencileri ve diğer bölümler arasındaki finansal bilgi düzeyi karşılaştııılmıştır. } \\
\text { Anketten elde edilen sonuca göre işletme öğrencilerinin finansal okuryazarlık se- } \\
\text { viyeleri diğer bölümlere göre yüksek çıkmışırı. }\end{array}$ \\
\hline Barış (2016) & $\begin{array}{l}\text { Bu araştırmada Gaziosmanpaşa Üniversitesi öğrencilerine uygulanan anket } \\
\text { çalışması sonucunda öğrencilerin finansal okuryazarlık seviyeleri ölçülmüştür. } \\
\text { Anketten çlkan sonuca göre öğrencilerin temel düzeydeki bilgi düzeylerinin } \\
\text { yeterli fakat ileri düzeydeki bilgi düzeylerinin düşük olduğu belirlenmiştir. } \\
\text { Ayrıca cinsiyet faktörü açsından da kı öğrencilerin bilgi düzeylerinin erkek } \\
\text { öğrencilere göre daha yüksek seviyede olduğu belirlenmiştir. }\end{array}$ \\
\hline $\begin{array}{l}\text { Elmas ve } \\
\text { Yilmaz (2016) }\end{array}$ & $\begin{array}{l}\text { Bu çalışma öğgencilerin finansal okuryazarlık düzeyini belirlemek amacıyla } \\
\text { yapılmıştır. Öğrenim gördükleri üniversite eğitiminin finansal bilgi düzeylerine } \\
\text { olumlu etki gösterip göstermediğine dikkat edilmiştir. Yapılan bu araştırma so- } \\
\text { nucunda elde edilen verilerde öğrencilerin finansal okuryazarlık başarı düzeyle- } \\
\text { rinin beklenilen ortalamanın altında kaldığı belirlenmiştir. }\end{array}$ \\
\hline OECD (2012) & $\begin{array}{l}\text { Birçok ülkede yapılan çalışmalar tüketicilerin yeterli finansal okuryazarlık } \\
\text { altyapısına sahip olmadıklarını göstermektedir. Yapılan anket araştırmaları so- } \\
\text { nucunda insanların yeterli düzeyde finansal bilgi, algı ve farkındalığa sahip } \\
\text { olmadıkları testip edilmiştir. Bu sebeple insanların finansal bilgi düzeylerini } \\
\text { artırmak için çalışmak oldukça önemlidir. }\end{array}$ \\
\hline $\begin{array}{l}\text { Alkaya ve } \\
\text { Yağlı (2015) }\end{array}$ & $\begin{array}{l}\text { Nevşehir Hacı Bektaş Veli Üniversitesi İktisadi ve İdari Bilimler Fakültesi öğren- } \\
\text { cilerine yapılan bu çalışmada öğrencilerin finansal bilgi düzeyleri üzerinde du- } \\
\text { rulmuştur. Yapılan analizlerin sonucunda öğrencilerin finansal bilgi açısından } \\
\text { yeterli düzeyde olmadıkları kanısına varılmıştır. }\end{array}$ \\
\hline
\end{tabular}




$\begin{array}{lll}\text { Çinko } & \text { vd. } & \text { Bu çalışmada üniversite öğrencilerinin finansal bilgi düzeylerinin tespit edilmesi } \\ \text { (2016) } & & \text { hedeflenmiştir. Bu amaçla Marmara Üniversitesi'nin çeşitli fakültelerindeki } \\ & \text { öğrenciler üzerinde yaplan anket çalışmasının sonucunda öğrencilerin sorula- } \\ & \text { nanket sorularına \%56 oranında doğru cevap verdikleri belirlenmiştir. }\end{array}$

\section{Finansal Okuryazarlık}

2008 yılında Amerika Birleşik Devletleri'nde patlak veren ve tüm dünyayı etkisi altına alan Mortgage krizi, toplumu inşa eden her bireyin finansal açıdan temel düzeyde bilgi sahibi olması gerekliliğinin ortaya çıkmasına vesile oldu. Nitekim finansal konularda bilgi sahibi olmayan bireylerden oluşan toplum, ekonomik ve finansal gelişmelere doğru tepkiler veremez ve gerek ulusal gerekse uluslararası çapta gerçekleşebilecek olası krizlere karşı kendisini koruyamaz. Bireylerin finansal gelişmelere karşı algısı ve oluşabilecek bu krizlere karşı alacağı davranışlar bütünün bilinçli olma durumuna ise genel olarak finansal okuryazarlık denilmektedir.

Finans dünyasında ciddi olarak dillendirilmesi üzerinden henüz 15 yıl bile geçmemiş olan finansal okuryazarlık, henüz tanımlama konusunda kesin mutabakata varılmamış bir kavramdır (Saraç, 2014, s.4). Finansal okuryazarlık kavramının birçok farklı yönelimde tanımlamaları mevcuttur. Bunlara kısaca bakacak olursak;

- Finansal bilgileri doğru kavrama ve etkin karar alma (Noctor, 1992)

- Kişilerin edindiği finansal bilgilerle algılarını ve davranışlarını yönlendirebilmesi (Holzmann, 2010)

- Günlük hayatta karşılaşılan finansal sorunlara çözüm getirme (Er vd., 2014, s.114)

- Kişinin finansal ürünler hakkında bilgi sahibi olunması ve risk vb. durumları karşılayabilme yeteneği (OECD)

- Tüketim ekonomisi içerisinde en doğru tercihleri seçme ve yatırım yapma (Courchane vd., 2008, s.126) vb.

özellikleri ve durumları merkeze alarak yapılan birçok tanımlama mevcuttur.Kavramı en geniş ve en sade haliyle tanımlayacak olursak, finansal okuryazarlık; kişilerin temel düzeyde finans bilgisine sahip olması, bu bilgiler ışığında finansal konularını doğru algılaması ve günlük hayattaki finansal davranışlarını düzenlemesidir.

Finansal okuryazarlık düzeyinin yüksek tutulmasındaki en önemli amaç, kişilerin harcama ve tasarruflarını düzenlemeleri, günlük hayatta 
karşılaşılan riskleri ve tercihleri iyi değerlendirmeleri ve kısa ve uzun vadeli planlamalar yaparak hayatlarına yön vermeleri olarak belirtilebilir.

Finansal okuryazarlık seviyesi yüksek olan bireylerden oluşan toplumda, harcamalar düzenli yapılır, tasarrufa önem verilir. Yapılan tasarruflar yastık altında bekletilmez, finansal piyasalarda aktif olarak değerlendirilir. Finansal piyasalarda değerlendirilen tasarruflar, ülke ekonomisinin en önemli paydaşlarından olan şirketlerin ve devletlerin daha ucuza kaynak bulmasına olanak sağlar. Böylelikle genel ekonomik dengede verilen açıkların azalmasına yardımcı olur. Finansal okuryazarlık düzeyi yüksek olan bireyler, doğrudan kendi ailelerinin refahına, dolaylı yoldan ise ülkenin refahına katkıda bulunmaları sebebiyle toplum ve ülkeler için kritik öneme sahiptirler.

Finansal okur yazarlık seviyesi, kendi içerisinde, bireylerin eğitim seviyesine bağlı olarak iki türe ayrılabilir. Bunlar, temel düzey ve ileri düzey finansal okur yazarlıktır. Temel düzey finansal okur yazarlık faiz, enflasyon, risk, getiri, tasarruf gibi temel düzey finans ve ekonomi bilgilerinden oluşmaktadır. İleri düzey finansal okur yazarlık ise paranın zaman değeri, tahvil-hisse senedi farklılıkları, vade-risk-getiri ilişkisi, sermaye piyasalarının özellikleri gibi detaylı finans bilgilerinin bilinmesi ve kullanılması durumunu kapsar. Temel düzey ve ileri düzey finansal okur yazarlık düzeyini belirleyen en temel unsur eğitim olması sebebiyle, iktisadi idari bilimler fakültesinden mezun bireylerin ileri düzey finansal okur yazar olması, toplumun geri kalanının ise temel düzeyde finansal okur yazar olması beklenmektedir.

Finansal okuryazarlık kavramı tek bir ölçeğe verilen cevaplarla ölçülememektedir. Finansal okuryazarlık kavramı içerisinde, temel finansal bilgi, finansal konuları algılama düzeyi ve gündelik hayattaki finansal davranış gibi 3 temel bileşen bulunduğu söylenebilir.

Temel finans bilgisi, kişilerin basit-bileşik faiz, faiz-enflasyon ilişkisi, risk, getiri, vade, finansal yatırım araçları, finans piyasaları ve tasarruf gibi konularda temel bilgilere sahip olma, bu bilgiler hakkında konuşabilme durumuna denilebilir.

Finansal okuryazarlığı oluşturan bileşenlerden biri olan finansal algı, mikroekonomik ve makroekonomik gibi anlaşılması zor alt disiplin dallarındaki temel hareketleri ve etkileri kişinin karmaşık ve zor olarak algılamaması olarak düşünülebilir. Kişiler, başta karmaşık görünen 
konuları, temel düzeyde eğitim aldıktan sonra daha kolay anlar, bu konulara daha çok ilgi duymaya başlar ve bu konuları gündelik hayatında daha kolay konumlandırmaya başlar.

Finansal okuryazarlığın bir diğer bileşeni olan finansal davranış, kişilerin gündelik hayattaki harcama ve tasarruf hareketlerinin bilinçli yapılması olarak tanımlanabilir. Kişiler, temel düzeyde finansal bilgiye sahip olup finansal konuları zihinlerinde daha rahat konumlandırdıktan sonra, nihai olarak günlük hayattaki harcama, tasarruf gibi davranışlarını yönlendirebilirler. Tüm bu sebeplerdendir ki finansal okuryazarlığ oluşturan her bileşen sırasıyla son derece öneme sahiptir. Kişilerin doğru bir şekilde edindikleri temel bilgi ekonomik olayları daha rahat algılamasına, bu algilama sonucu kısa ve uzun vadeli finansal kararları daha sağlıklı vermelerine yardımcı olmaktadır.

\section{Yöntem}

$\mathrm{Bu}$ araştırma, iktisadi ve idari bilimler fakültesinde işletme bölümü okuyan, finans dersini başarıyla tamamlamış ve hiç finans dersi almamış öğrencilerin finansal okuryazarlık konusundaki bilgi düzeyini, finansal algılarını ve finansal konulardaki davranışlarını ölçmek amacıyla, karşılıklı veri toplam yöntemlerinden anket formu kullanılarak uygulanmiştır.

Araştırmanın önemi, finans dersini başarıyla tamamlamış ve hiç finans dersi almamış öğrencilerin finansal bilgi, algı ve davranış durumlarının karşılaştırılmasına olanak sağlamasıdır.

Araştırma, Aydın Adnan Menderes Üniversitesi İktisadi ve İdari Bilimler Fakültesi İşletme bölümü 1. ve 4. sınıf, birinci ve ikinci öğretim öğrencileri üzerinde uygulanmıştır. Bu araştırma yapılırken birinci sınıfların hiç finans dersi almamış oldukları ve dördüncü sınıfların ise okulda verilen finans derslerini başarıyla tamamlamış oldukları varsayılmıştır.

Araştırmamızın evreni 280 kişiden oluşmaktadır. Evren büyüklüğüne bağlı olarak örneklem sayısı hesaplandığında yapılması gereken anket sayısı 152' dir. Bu bağlamda 280 kişiye anket yapılmış, 12 hatalı veya eksik bilginin olduğu anket çıkarıldıktan sonra analiz kapsamına 268 anket dahil edilmiştir. 
Anket verilerinin analizi için IBM SPSS Statistic 24.0 paket programı kullanılmıştır. Anket dağılım güvenirliliği için evrensel olarak kabul edilen Cronbach Alpha güvenirlilik katsayı değeri hesaplanmıştır. Cronbach's Alpha değerinin 0,70 'den büyük $0,95^{\prime}$ den küçük olması literatürde kabul gören aralıktır. Hesaplama sonucunda anketin 0,773 güvenirlilik katsayısına sahip olduğu tespit edilmiş olup, güvenilir kabul edilmiştir.

Anket formunun ilk bölümünde katılımcıların özelliklerini betimlemek üzere 6 adet demografik soru sorulmuştur. İkinci bölümde katılımcların finansal okuryazarlık bilgi düzeylerinin test edilmesi amacıyla faiz, enflasyon, risk, getiri, çeşitlendirme, finansal yatırım araçları, finansal piyasalar ve tasarruf konularında 12 adet soru sorulmuştur. Anketin ikinci ve üçüncü bölümlerinde katılımcıların finansal konuları algılamaları ve finansal konulardaki davranışlarını ölçmek amacıyla, 5'li likert yöntemi kullanarak 10'ar ifade yöneltilmiştir.

Araştırmamızın hipotezleri cinsiyet, finans dersi alma-almama ve aktif olarak bir işte çalışma-çalışmama değişkenleri ile belirlenmiştir

Toplumda cinsiyet farklılıkları sebebiyle çalışılan işlerin farklılaşması, kişilerin günlük yaşamdaki ilgilerini, algılarını ve davranışlarını yönlendirmektedir. Cinsiyetçi yaklaşımla erkeklerin ve kadınların farklı alanlardaki işlerde çalışması kişilerin ekonomiye ve finansa olan ilgi ve alg1 durumlarını değiştirmektedir. Bu ilgi ve algı farklılıkları toplumların kültürel genlerine işlemekte ve istemsizce nesilden nesile aktarılmaktadır. Bu sebeple çalışmamızda cinsiyet farklılıklarına göre oluşturulan hipotezler aşağıdaki gibidir:

- H1: Finansal okuryazarlık bilgi düzeyi cinsiyete göre anlamlı bir farklılık göstermektedir.

- H2: Finansal konuları algılama durumu cinsiyete göre anlamlı bir farkl1lık göstermektedir.

- H3: Günlük hayattaki finansal davranış durumlarındaki tutumlar cinsiyete göre anlamlı bir farklılık göstermektedir.

Finans dersini başarı ile tamamlamış ve finans dersini hiç almamış olan öğrenciler arasında finansal bilgi, alg1 ve davranış düzeylerinintest edilmesi araştırmamızın en temel amacıdır. Bu sebeple aşağıdaki hipotezler oluşturulmuştur: 
- H4: Finansal okuryazarlık bilgi düzeyi finans dersini alma durumuna göre anlamlı bir farklılık göstermektedir.

- H5: Finansal konuları algılama, finans dersini alma durumuna göre anlamlı bir farklılık göstermektedir.

- H6: Günlük hayattaki finansal davranış durumlarındaki tutumlar finans dersini alma durumuna göre anlamlı bir farklılık göstermektedir.

Bireylerin yaşamların idame ettirebilmeleri için paraya ihtiyaçları vardır. Üniversite öğrencilerinin büyük bir kısmı ailesinin, devletin ve bazı vakıfların sağladığı burs ve kredilerle, küçük bir kısmı ise üniversite eğitimi sırasında çalışarak geçimlerini sağlayacak parayı elde etmektedirler. Çalışan bireylerle çalışmayan bireylerin maddi konulardaki algılarının ve davranışlarının farklılık göstermeleri beklenebilir.Aktif olarak bir işte çalışan öğrencilerin finansal bilgi, algı ve davranışlarının çalışmayan öğrencilere göre düzey ve yönelimlerini ölçmek için belirlenen hipotezler aşağıda verilmiştir:

- H7: Aktif olarak bir işte çalışan öğrencilerle, bir işte çalışmayan öğrencilerin finansal bilgi düzeyleri arasında anlamlı bir farklılık vardır.

- H8: Aktif olarak bir işte çalışan öğrencilerle, bir işte çalışmayan öğrencilerin finansal konuları algılamalarında anlamlı bir farklılık vardır.

- H9: Aktif olarak bir işte çalışan öğrencilerle, bir işte çalışmayan öğrencilerin günlük hayattaki finansal davranışları arasında anlamlı bir farklılık vardır.

\section{Uygulama}

Anket katılımcılarının kişisel özelliklerini betimleyen demografik sorularına ait sıklık durumu aşağıdaki tabloda yer almaktadır. 
Tablo 2. Katılımcıların Demografik Dă̆ılımları

\begin{tabular}{llll}
\hline & Tercih & Frekans & Yüzde \\
\hline Cinsiyet & Erkek & 123 & 45,9 \\
& Kadın & 145 & 54,1 \\
\hline \multirow{3}{*}{ Yaş } & $17-19$ & 27 & 10,1 \\
& $20-22$ & 130 & 48,5 \\
& $23-25$ & 107 & 39,9 \\
\hline Sınıf & 26 ve üstü & 4 & 1,5 \\
& 1. sinıf & 85 & 31,7 \\
\hline Program & 4. sinıf & 183 & 68,3 \\
\hline Aylık gelir & Birinci öğretim & 143 & 53,4 \\
& İkinci öğretim & 125 & 46,6 \\
& $0-500$ & 69 & 25,7 \\
& $501-750$ & 72 & 26,9 \\
& $751-1000$ & 59 & 22 \\
\hline Çalışma durumu & 1001 ve üstü & 68 & 25,4 \\
& Evet & 26 & 9,7 \\
& Hayır & 242 & 90,3 \\
\hline
\end{tabular}

Çalışmamızda işletme bölümü birinci sınıf öğrencileri 85 kişi, dördüncü sınıf öğrencileri ise 183 kişi olarak belirlenmiştir. Bu bariz fark işletme bölümü birinci sınıfına kayıtlı öğrencilerin sadece 90 kişiden oluşmasından kaynaklanmaktadır.

\section{Korelasyon Analizi}

Çalışmamızın bu bölümünde bilgi, algı ve davranış olarak gruplandırılmış anket sorularının birbirleriyle olan korelasyon analizi incelenmiştir.

Tablo 3. Korelasyon Katsayısı Tablosu

\begin{tabular}{llccc}
\hline & & Bilgi & Alg1 & Davranış \\
\hline Bilgi & PearsonCorrelation & 1 &,- 087 &,- 067 \\
& Sig. (2-tailed) & &, 155 &, 272 \\
\multirow{4}{*}{ Alg1 } & N & 268 & 268 & 268 \\
& PearsonCorrelation &,- 087 & 1 &, $406^{* *}$ \\
\multirow{4}{*}{ Davranış } & Sig. (2-tailed) &, 155 & &, 000 \\
& N & 268 & 268 & 268 \\
& PearsonCorrelation &,- 067 &, $406^{* *}$ & 1 \\
& Sig. (2-tailed) &, 272 &, 000 & \\
& $\mathrm{~N}$ & 268 & 268 & 268 \\
\hline
\end{tabular}

**. Correlation is significant at the 0.01 level (2-tailed). 
Çalışmamızda anket katılımcılarına yöneltilen soru gruplarının birbirleriyle olan korelasyonları incelendiğinde yukarıdaki sonuçlara ulaşılmıştır. Korelasyon analizi sonucunda bilgi sorularının algı soruları ile $-0,087$ dereceyle ve davranış soruları ile $-0,067$ dereceyle ters yönde ama güçsüz bir korelasyona sahip oldukları saptanmıştır.

Cinsiyete Göre Ö̆̆rencilerin Finansal Okuryazarlık Durumlarının ChiSquare ve T-Test Analiz Sonuçları

Tablo 4. Cinsiyete Göre Katılımcılarn Finansal Okuryazarlık Bilgi Soruları Ki- Kare Analizi Sonuçlar

\begin{tabular}{|c|c|c|c|c|c|}
\hline \multirow[b]{2}{*}{ Sorular } & \multirow{2}{*}{$\begin{array}{c}\text { Erkek } \\
\text { Doğru Yanit } \\
\text { Verenler } \\
\% \\
\end{array}$} & \multicolumn{2}{|c|}{ Kadın } & \multirow[b]{2}{*}{$\begin{array}{c}\text { Doğru Yanit } \\
\text { Vermeyenler } \\
\% \\
\end{array}$} & \multirow[b]{2}{*}{$p$} \\
\hline & & $\begin{array}{c}\text { Doğru Yanit } \\
\text { Vermeyenler } \\
\% \\
\end{array}$ & $\begin{array}{c}\text { Doğru Yanit } \\
\text { Verenler } \\
\%\end{array}$ & & \\
\hline Bilgi S1 & 81,1 & 18,9 & 77,5 & 22,5 & 0,005 \\
\hline Bilgi S2 & 33 & 67 & 37,1 & 62,9 & 0,125 \\
\hline Bilgi S3 & 64,5 & 35,5 & 73,6 & 26,4 & 0,021 \\
\hline Bilgi S4 & 82,6 & 17,4 & 81,3 & 18,7 & 0,957 \\
\hline Bilgi S5 & 47,2 & 52,8 & 47,5 & 52,5 & 0,271 \\
\hline Bilgi S6 & 53,7 & 46,3 & 53,8 & 46,2 & 0,066 \\
\hline Bilgi S7 & 43,4 & 56,6 & 28,3 & 71,7 & 0,160 \\
\hline Bilgi S8 & 66,4 & 33,6 & 64,5 & 35,5 & 0,600 \\
\hline Bilgi S9 & 52,8 & 47,2 & 53,5 & 46,5 & 0,813 \\
\hline Bilgi S10 & 68,3 & 31,7 & 59,4 & 40,6 & 0,132 \\
\hline Bilgi S11 & 14,6 & 85,4 & 11,9 & 88,1 & 0,001 \\
\hline Bilgi S12 & 46,3 & 53,7 & 53,1 & 46,9 & 0,487 \\
\hline
\end{tabular}

H1 hipotezinin test edilmesi için Chi-Square analizi, H2 ve H3 hipotezlerinin test edilmesi için bağımsız örneklemlere uygulanan T-Testi analizi uygulanmıştır.

H1 hipotezinin testi için bilgi sorularının her birine ayrı ayrı cinsiyet değişkeni ile Chi-Square testi uygulanmıştır. Uygulama sonucu her soru için elde edilen doğru cevap verenlerin ve doğru cevap vermeyenlerin yüzdeleri cinsiyet dağılımına göre yukarıdaki tabloda verilmiştir. Ayrıca tabloda her bir soru için Chi-Square anlamlılık değeri de verilmiştir.

Chi-Square analizi ile ulaşılan sonuçlar neticesinde sadece S1, S3 ve S11 sorularının cevapları H0 hipotezini doğrulamaktadır. Diğer 9 bilgi sorusunun sonucunda ise finansal bilgi düzeyinde cinsiyete göre herhangi 
anlamlı bir farklılık bulunmamaktadır. Bu sebeple $\mathrm{H} 1$ hipotezi, büyük oranda anlamlılık kazanmamıştır ve reddedilmiştir.

H2 hipotezinin testi için katılımcılara yöneltilen finansal algı sorularına verilen cevaplar ile cinsiyet değişkeni Bağımsız Örneklem T-Test analizine tabi tutulmuştur. T-Testi analizi sonuçları aşağıdaki tabloda belirtilmiştir.

Tablo 5. Cinsiyete Göre Katılımcıların Finansal Okuryazarlık Algı Sorularn T Test Analiz Sonuçları

\begin{tabular}{lllllll}
\hline Cinsiyet & $\mathbf{N}$ & Ortalama & Std. Sapma & $\mathbf{t}$ & $\mathbf{d f}$ & $\mathbf{p}$ \\
\hline Erkek & 123 & 3,6947 & 0,68982 & \multirow{2}{*}{1,692} & \multirow{2}{*}{266} & \multirow{2}{*}{0,092} \\
Kadın & 145 & 3,5626 & 0,58754 & & & \\
\hline
\end{tabular}

T-Test analizi sonuçlarına bakıldığında $\mathrm{p}$ değerinin 0,05 'den büyük olduğu görülmektedir. Bu durumda cinsiyete göre finansal konuları algılamada anlamlı bir farklılık bulunmadığı sonucuna ulaşılıp, $\mathrm{H} 2$ hipotezi reddedilmiştir.

H3 hipotezinin testi için finansal davranış sorularına verilen yanıtlarla cinsiyet değişkenine Bağımsız Örneklem T-Test analizi uygulanmıştır. TTest analiz sonuçları aşağıdaki tabloda verilmiştir.

Tablo 6. Cinsiyete Göre Katılımcıların Finansal Okuryazarlık Davranış Soruları T Test Analiz Sonuçlarn

\begin{tabular}{lllllll}
\hline Cinsiyet & $\mathbf{N}$ & Ortalama & Std. Sapma & $\mathbf{t}$ & $\mathbf{d f}$ & $\mathbf{p}$ \\
\hline Erkek & 123 & 3,4293 & 0,70868 & \multirow{2}{*}{$-1,851$} & \multirow{2}{*}{230,658} & \multirow{2}{*}{0,066} \\
Kadın & 145 & 3,5755 & 0,56005 & & & \\
\hline
\end{tabular}

T-Test analizi sonuçlarında $p$ değerinin $0,05^{\prime}$ den büyük olduğu görülmektedir. Buna göre finansal davranışın kadın veya erkek üzerinde anlamlı bir şekilde dağılmadığı anlaşılıp, H3 hipotezi reddedilmiştir.

Genel olarak bakıldığında, finansal bilgi, alg1 ve davranışlarda cinsiyete göre herhangi bir anlamlı farklılığa rastlanılmamış olup, bilgi, algı ve davranışın erkekler ve kadınlarda aynı yönelimde ve düzeyde olduğu söylenebilir. 
Finans Dersi Alma Durumuna Göre Öğrencilerin Finansal Okuryazarlık Durumlarmın Chi-Square ve T-Test Analiz Sonuçlarn

H4 hipotezinin doğrulanması için Chi-Square analizine, H5 ve H6 hipotezinin doğrulanması için Bağımsız Örneklem T-Test analizine başvurulmuştur.

Tablo 7. Sınıflarına Göre Katılımcıların Finansal Okuryazarlık Bilgi Soruları KiKare Analizi Sonuçları

\begin{tabular}{lccccc}
\hline \multirow{2}{*}{ Sorular } & \multicolumn{2}{c}{ 1. sınf } & \multicolumn{2}{c}{ 4. sınıf } & \\
& $\begin{array}{c}\text { Doğru } \\
\text { YanitVerenler } \\
\%\end{array}$ & $\begin{array}{c}\text { Doğru Yanıt } \\
\text { Vermeyenler } \\
\%\end{array}$ & $\begin{array}{c}\text { Doğru } \\
\text { Yanit Verenler } \\
\%\end{array}$ & $\begin{array}{c}\text { Doğru Yanit } \\
\text { Vermeyenler } \\
\%\end{array}$ & p \\
\hline Bilgi S1 & 62,4 & 27,6 & 87,2 & 22,8 & \\
Bilgi S2 & 26,3 & 73,7 & 39,3 & 60,7 & 0,000 \\
Bilgi S3 & 57,6 & 42,4 & 75 & 25 & 0,000 \\
Bilgi S4 & 72,9 & 27,1 & 86,1 & 13,9 & 0,028 \\
Bilgi S5 & 19 & 81 & 60,6 & 39,4 & 0,000 \\
Bilgi S6 & 54,1 & 45,9 & 53,6 & 46,4 & 0,001 \\
Bilgi S7 & 31 & 69 & 37,5 & 62,5 & 0,000 \\
Bilgi S8 & 56,3 & 33,6 & 69,4 & 35,5 & 0,001 \\
Bilgi S9 & 38,8 & 61,2 & 59,9 & 40,1 & 0,005 \\
Bilgi S10 & 63,5 & 36,5 & 63,5 & 36,5 & 0,260 \\
Bilgi S11 & 12,9 & 87,1 & 13,3 & 86,7 & 0,000 \\
Bilgi S12 & 40 & 60 & 54,7 & 45,3 & 0,000 \\
\hline
\end{tabular}

H4 hipotezinin test edilmesi için, finans dersini alan 4. Sınıf öğrencilerine ve finans dersini hiç almamış 1 . Sınıf öğrencilerine yöneltilen finansal bilgi sorularının her biri ayrı ayrı Chi-Square analizine tabi tutulmuştur. Chi-Square analizinin sonucunda her bir soru için ayrı ayrı verilen doğru yantlar ve doğru olmayan yanıtlar aşağıdaki tabloda verilmiştir. Ayrıca tabloya her soru analizinde ulaşılan anlamlılık değeri eklenmiştir.

Finans dersi alma durumuna göre Chi-Square analizinin sonuçlarına bakılacak olunursa, tek bir soru hariç diğer tüm sorularda anlamlı bir farklılık var olduğu sonucuna ulaşılır. Sadece 10 . Sorunun yantlarında finans dersi alma durumu anlamlı bir farklılık yaratmamıştır. Bu durumda H4 hipotezi yüksek derecede doğrulanarak kabul edilmiştir.

H5 hipotezinin doğrulanabilmesi için uygulanan T-Test uygulamasının sonuçları aşağıdaki tabloda verilmiştir. 
Tablo 8. Sınıflarına Göre Katılımcıların Finansal Okuryazarlık Algı Sorulan T Test Analiz Sonuçları

\begin{tabular}{lllllll}
\hline Sinıf & $\mathbf{N}$ & Ortalama & Std. Sapma & $\mathbf{t}$ & $\mathbf{d f}$ & $\mathbf{p}$ \\
\hline 1 & 85 & 3,7669 & 0,70931 & \multirow{2}{*}{2,535} & \multirow{2}{*}{266} & \multirow{2}{*}{0,012} \\
4 & 183 & 3,5565 & 0,59343 & & & \\
\hline
\end{tabular}

H5 hipotezinin analiz edilmesi için uygulanan T-Test analizinin sonucunda, p değerinin 0,05 'den küçük çımasıyla birlikte finansal konuları algilama konusunda finans dersi alma durumu ve hiç finans dersi almama durumu arasında anlamlı bir farklılığın varlığından bahsedilebilir. Bu durumda $\mathrm{H} 5$ hipotezi doğrulanmış ve kabul edilmiştir.

H6 hipotezinin analiz edilmesi için uygulana T-Test uygulamasının sonuçları aşağıdaki tabloda verilmiştir.

Tablo 9. Sınıflarına Göre Katılımcıların Finansal Okuryazarlık Davranış Soruları T Test Analiz Sonuçları

\begin{tabular}{lllllll}
\hline Sinif & $\mathbf{N}$ & Ortalama & Std. Sapma & $\mathbf{t}$ & $\mathbf{d f}$ & $\mathbf{p}$ \\
\hline 1 & 85 & 3,5217 & 0,73668 & \multirow{2}{*}{0,214} & \multirow{2}{*}{135,041} & \multirow{2}{*}{0,831} \\
4 & 183 & 3,5022 & 0,58485 & & & \\
\hline
\end{tabular}

T-Test sonucunda $\mathrm{p}=0,831$ sonucuna ulaşılmıştır. Bu durumda günlük hayattaki finansal davranışlar üzerinde finans dersi almanın herhangi bir etkisinin olmadığından bahsedilebilir ve böylelikle H6 hipotezi reddedilir.

\section{Aktif Olarak Bir İşte Çalışma Durumuna Göre Öğrencilerin Finansal Okuryazarlık Durumlarıın Chi-Square ve T-Test Analiz Sonuçlar}

H7 hipotezin analiz edilmesi için katılımcılara yöneltilen her bir bilgi sorusu ile çalışma durumu değişkeni, Chi-Square yöntemiyle ayrı ayrı analiz edilmiştir. H7 hipotezinin test edilmesi sonucunda, çalışan ve çalışmayan öğrenciler tarafından her bir bilgi sorusuna verilen doğru cevapların yüzdesel oranı ve her bir sorunun analizinde ulaşılan anlamlılık değerleri tabloda belirtilmiştir. 
Tablo 10. Çalışma Durumlarına Göre Katılımcıların Finansal Okuryazarlık Bilgi Soruları Ki-Kare Analizi Sonuçları

\begin{tabular}{lccccc}
\hline & \multicolumn{2}{c}{ Çalışan } & \multicolumn{2}{c}{ Çalışmayan } \\
\cline { 2 - 6 } Sorular & $\begin{array}{c}\text { Doğru Yant } \\
\text { Verenler \% }\end{array}$ & $\begin{array}{c}\text { Doğru Yanit } \\
\text { Vermeyenler } \\
\%\end{array}$ & $\begin{array}{c}\text { Doğru Yanıt } \\
\text { Verenler \% }\end{array}$ & $\begin{array}{c}\text { Doğru Yanıt } \\
\text { Vermeyenler } \\
\%\end{array}$ & p \\
\hline Bilgi S1 & 88 & 12 & 78,2 & 21,8 & 0,451 \\
Bilgi S2 & 38,1 & 61,9 & 35 & 65 & 0,958 \\
Bilgi S3 & 69,2 & 30,8 & 69,5 & 30,5 & 0,700 \\
Bilgi S4 & 87,5 & 12,5 & 81,3 & 18,7 & 0,644 \\
Bilgi S5 & 50 & 50 & 47,1 & 52,9 & 0,902 \\
Bilgi S6 & 42,3 & 57,7 & 55 & 45 & 0,179 \\
Bilgi S7 & 52 & 48 & 33,6 & 66,4 & 0,037 \\
Bilgi S8 & 80,8 & 19,2 & 63,7 & 36,3 & 0,062 \\
Bilgi S9 & 76,9 & 23,1 & 50,6 & 49,4 & 0,038 \\
Bilgi S10 & 61,5 & 38,5 & 63,8 & 36,2 & 0,933 \\
Bilgi S11 & 23,1 & 36,9 & 12,1 & 87,9 & 0,256 \\
Bilgi S12 & 65,4 & 34,6 & 48,3 & 51,7 & 0,256 \\
\hline
\end{tabular}

Chi-Square analizi sonucu elde edilen verilere bakıldığında sadece S7 ve S9 sorularına verilen yanıtlarda çalışan öğrenciler ve çalışmayan öğrenciler arasında anlamlı bir farklılık tespit edilmiştir. Diğer sorularda anlamlı bir farklılık tespit edilmeyip, H7 hipotezi büyük oranda reddedilmiştir.

H8 hipotezini analiz etmek için katılımcılara yöneltilen finansal alg1 ifadeleri ile çalışma durumu değişkeni T-Test analizine tabi tutulmuş, sonuçlar aşağıdaki tabloda verilmiştir.

Tablo 11. Çalışma Durumlarına Göre Katılımcıların Finansal Okuryazarlık Algı Soruları T Test Analiz Sonuçları

\begin{tabular}{lllllll}
\hline Durum & $\mathbf{N}$ & Ortalama & Std. Sapma & $\mathbf{t}$ & $\mathbf{d f}$ & $\mathbf{p}$ \\
\hline Çalışan & 26 & 3,9000 & 0,61903 & \multirow{2}{*}{2,345} & \multirow{2}{*}{266} & \multirow{2}{*}{0,020} \\
Çalışmayan & 242 & 3,5935 & 0,63487 & & & \\
\hline
\end{tabular}

Finansal algı durumu ve çalışma durumu değişkeni T-Test analizini sokulmuş ve anlamlılık değeri 0,05'den düşük çıkmıştır. Böylelikle, çalışma durumuna göre finansal konuları algılama durumu arasında anlamlı bir farklılık bulunup, H8 hipotezinin doğruluğu kabul edilmiştir. H9 hipotezinin test edilmesi için günlük yaşamdaki finansal davranışları ölçen sorularla çalışma durumu değişkeni T-Test analizine tabi tutulmuştur. Analiz sonucu aşağıdaki tabloda verilmiştir. 
Tablo 12. Çalışma Durumlarına Göre Katılımcıların Finansal Okuryazarlık Davranış Soruları T Test Analiz Sonuçlan

\begin{tabular}{lllllll}
\hline Durum & $\mathbf{N}$ & Ortalama & $\begin{array}{l}\text { Std. } \\
\text { Sapma }\end{array}$ & t & df & p \\
\hline Çalışan & 26 & 3,6846 & 0,65830 & 1,491 & 266 & 0,137 \\
Çalışmayan & 242 & 3,4894 & 0,63158 & & & \\
\hline
\end{tabular}

Günlük hayattaki finansal davranışları ölçen davranış ifadeleri ile çalışma durumu değişkeninin analiz edildiği T-Test yöntemi sonucu çıkan p değeri 0,05'den büyük olarak tespit edilmiş ve davranış ile çalışma durumu arasında anlamlı bir farklılık bulunmayarak H9 hipotezi reddedilmiştir.

\section{Sonuç ve Öneriler}

Araştırmamızda cinsiyet, finans dersi alma ve sınıf değişkenlerine verilen cevaplar arasında anlamlı farklılıklar tespit edilmeye çalışılmıştır. Çalışmamıza 268 öğrenci katılmıştır, katılımcıların \%48,5'u 20-22 yaş aralığında, \%68,3'ü 4 . sınıf, \%90,3'ü ise aktif olarak çalışmayan üniversite öğrencilerden oluşmaktadır. Diğer demografik değişkenlerde bariz bir farklılığa rastlanılmamıştır.

Anket formumuz, finansal okur yazarlığın 3 bileşeninden oluşmaktadır. Bunlar; Finansal bilgi, finansal algı ve finansal davranıştır. Bu bileşenlere uygulanan korelasyon analizi sonucunda, finansal bilgi ve finansal algı cevapları arasında-0,087, finansal bilgi ve finansal davranış cevapları arasında $-0,067$ ve finansal algı ve finansal davranış cevapları arasında 0,406 kuvvetlerinde korelasyon değerlerine ulaşılmıştır. Finansal bilgi cevaplarının finansal algı ve finansal davranış cevapları arasında zayıf ve ters yönlü bir ilişki olduğu tespit edilmiştir. Finansal algı cevapları ile finansal davranış cevapları arasında ise orta kuvvette pozitif yönlü bir ilişkiye rastlanılmıştır.

Çalışmamıza katılan öğrencilerin, çalışma durumlarına göre finansal algı durumlarında anlamlı bir farklılık tespit edilmiştir. Çalışan öğrencilerin finansal algı sorularına verdikleri cevaplar göz önüne alındı̆̆ında 3,90 ortalamayla, çalışmayan öğrencilere göre daha yüksek farkındalık seviyesine sahip oldukları söylenebilir. Finansal davranış cevaplarında, 
çalışma durumuna göre anlamlı bir fark gözetilmemiştir. Çalışma durumu, finansal algılamada anlamlı bir farklılık oluştursa da finansal davranışlar üzerinde anlamlı bir farklılık oluşturmamaktadır.

Çalışmamızın esas amacı, finans eğitiminin önemini göstermektir. Öğrenciler üzerinde yapılan anket çalışması ile finans dersini alma durumunun finansal bilgi üzerinde büyük bir etkiye sahip olduğu sonucuna ulaşılmıştır. Finansal bilgi yetkinliğinin en belirgin olduğu sorular Bilgi S1, S3, S5 ve S9'dur. Bilgi S1'e 1. siniflar \%62,4, 4.siniflar \%87,2 oranında doğru cevap vermişlerdir. Bilgi S3'e verilen yanıtlara bakıldığında 1 . sinıflar \%57,6, 4. sınıflar \%75 oranında doğru yanıt vermişlerdir. Bilgi S5' in sonuçlarında ise 1. Sinıflar \%19, 4. Sınıflar \%60,6 oranında doğru cevap vermişlerdir. Bir diğer soru olan Bilgi S9'un cevaplarma bakıldığında, 1 . Sınıfların $\% 38,8,4$. Sınıfların $\% 59,9$ oranında doğru cevap verdikleri görülmektedir. Bu bağlamda finans dersinin faiz, getiri-risk ilişkisi, yatırım piyasalarının yapısı ve yatırım araçlarının özelliklerinin öğrenilmesi hususunda etkili olduğu söylenebilir. Bir diğer açıdan bakacak olursak, 1. Sınıfların risk içeren sorularda diğer sorulara nazaran daha başarısız oldukları gözlenmiştir.

Finansal okur yazarlık bileşenlerinden biri olan finansal algı konusunda, 1 . Sinıflar ile 4. Sinıflar arasında bariz bir fark bulunmaktadır, beklenilen 4 . Sınıfların finansal alg1 düzeylerinin daha yüksek olması iken, 1. Sinıfların finansal algı düzeyleri daha yüksektir. Bunun yanında 1 . Sinıflar ile 4. Sinıflar arasinda algisal bir farklılık varken, bu algı durumu davranışsal olarak kendini göstermemektedir. Bütün bu verilerin ışığında, temel finansal bilgi konularının zorunlu eğitimin son halkası olan ortaöğretim düzeyinde verilmesi tavsiye edilmektedir. Böylelikle toplumun tüm fertlerinde temel finansal bilgi konularının erken yaşlarda kazandırılması sağlanabilir. Her birey yüksek öğrenime devam etmek zorunda değildir, finansal bilgi konularının ortaöğretim düzeyinde verilmeye başlanması ile eğitimine devam etmek istemeyen ya da erken yaşta iş hayatına giren bireyler finansal konularda bilgilendirilmiş olurlar. $\mathrm{Bu}$ sayede toplumun tüm bireyleri temel düzeyde finansal okur yazarlık bilgisine sahip olurlar. 


\title{
EXTENDED ABSTRACT
}

\section{The Effect of Students Finance Learning Situation on the Level of Financial Literacy: A Case of Nazilli}

\author{
Umut Tolga Gümüş - Murat Kutay Pailer \\ Adnan Menderes University
}

Financial literacy; to have basic knowledge of finance, to perceive financial issues correctly and to regulate financial behaviors in daily life. The most important objective in keeping the financial literacy level high is to regulate people's spending and savings, to evaluate risks and preferences and to direct their lives by making short and long term plans. In a society consisting of individuals with a high level of financial literacy, expenditures are made regularly and saving is given importance. Savings in the financial markets allow companies and governments, one of the most important stakeholders of the national economy, to find cheaper resources. Thus, it helps to reduce the deficits in the general economic balance. Individuals with a high level of financial literacy are critical for society and countries as they contribute directly to the welfare of their families and indirectly to the welfare of the country. The level of financial literacy can be divided into two types, depending on the level of education of individuals. These are basic and advanced financial literacy. Basic level financial literacy consists of basic level financial and economic information such as interest, inflation, risk, return, savings. Advanced financial literacy covers the knowledge and use of detailed financial information such as time value of money, bond-stock differences, maturity-risk-return relationship, and characteristics of capital markets. Since education is the most basic element determining basic and advanced financial literacy levels, it is expected that individuals graduated from the Faculty of Economics and Administrative Sciences will be advanced financial literate and the rest of the society will be financial literate.

The concept of financial literacy cannot be measured by responses to a single scale. In the concept of financial literacy, it can be said that there are 3 basic components such as basic financial knowledge, level of perception 
of financial issues and financial behavior in daily life. Basic knowledge of finance, simple-compound interest, interest-inflation relationship, risk, return, maturity, financial investment instruments, financial markets and savings, such as having basic knowledge of the subject can be said to talk about this information. Financial perception, which is one of the components of financial literacy, can be thought of as not being perceived as complex and difficult by the basic movements and effects in sub-disciplinary branches such as microeconomics and macroeconomics. Financial behavior, which is another component of financial literacy, can be defined as making conscious spending and saving movements in daily life. After having a basic level of financial knowledge and better positioning financial issues in their minds, people can ultimately direct their behavior such as spending and saving in daily life.

Financial literacy does not only cover transactions carried out in financial markets with financial instruments. Individuals also benefit from financial literacy knowledge while solving the problems they face in their daily lives. Since individuals need to create a spending plan separate from their families in the period they start university education, they try to establish the income expenditure balance for the first time in this period. This research has been applied by using a questionnaire form of mutual data total methods in order to measure the level of knowledge, financial perceptions and behaviors of financial literacy students who have successfully completed finance course and have never taken finance course.

The importance of the research is that it enables the comparison of financial knowledge, perception and behavior of the students who have successfully completed the finance course and have not taken any finance course. The research was applied to the first and fourth year students of the Department of Business Administration, Faculty of Economics and Administrative Sciences of Aydın Adnan Menderes University. In this research, it is assumed that first year students have not taken any finance courses and fourth year students have successfully completed the finance courses given in the school. The universe of our study consists of 280 people. In this context, 280 people were surveyed, and after the survey with 12 incorrect or incomplete information, 268 questionnaires were included in the analysis. Cronbach's Alpha value was found to be 0.773 and it was accepted as reliable. In the first part of the questionnaire, 6 demographic 
questions were asked to describe the characteristics of the participants. In the second part, 12 questions were asked about interest, inflation, risk, return, diversification, financial investment instruments, financial markets and savings in order to test the participants' level of financial literacy. In the second and third parts of the questionnaire, in order to measure the perceptions and behaviors of the participants on financial issues, 10 expressions were directed using 5-point Likert method.

As a result of the correlation analysis between the answers given to financial literacy components, it was found that the information questions had an inverse but weak correlation with perception questions and behavior questions with -0.087 degrees and -0.067 degrees. Gender variable was analyzed separately with 3 different question groups. As a result of the analysis, it was concluded that the gender variable does not have a significant difference in financial information, financial perception and financial behavior parameters. As a result of the analysis conducted with 3 different question groups for taking the finance course variable, it was seen that taking finance course created a significant difference in financial knowledge and perception levels. As a result of the analysis of the status of actively working in a job, it was observed that there was no significant difference in the level of financial knowledge and financial behavior and there was a significant difference in financial perception.

Along with all these data, it is recommended that basic financial information subjects be given at the secondary level which is the last link of compulsory education. In this way, it can be ensured that basic financial information issues are gained at an early age in all members of the society. Not all individuals are required to continue their higher education. Upon the introduction of financial information subjects at secondary level, individuals who do not wish to continue their education or who enter the business life at an early age are informed about financial matters.

\section{Kaynakça / References}

Alkaya, A. ve Yağlı, İ., (2015). Finansal okuryazarlık-finansal bilgi, davranış ve tutum: Nevşehir Hacı Bektaş Veli Üniversitesi İ̈BF öğrencileri üzerine bir uygulama. Uluslararası Sosyal Araştırmalar Dergisi, 8 (40), 585-599. 
Barış, S., (2016). Finansal okuryazarlık ve bütçeleme davranışı: Üniversite öğrencileri üzerine bir araştırma. TESAM Akademi Dergisi, 3(2), 1338.

Barmakı, N. Ve Şener A., (2017). Üniversite öğrencilerinin finansal okur yazarlık düzeyleri. Journal of CurrentResearches on SocialSciences, 7 (3), 67-88.

Çinko M., Avcı E., Ergun S. ve Tekçe M., (2017). Üniversite öğrencilerinin finansal okuryazarlık düzeyleri: Marmara Üniversitesi örneği. Marmara Business Review, 2 (1), 25-50.

Coşkun S., (2016). Üniversite öğrencilerinin finansal davranış ve tutumlarının belirlenmesi: Finansal okuryazarlık algıları üzerine bir araştırma. Insan ve toplum bilimleri araştırmaları dergisi, 5(7), 22472258.

Courchane, M., Gailey A. ve Zorn, P. (2008). Consumer creditliteracy: Whatpriceperception? Elsevier, Journal of Economicsand Business, 60, 125-138.

Danışman E., Sezer D. ve Gümüş U.T. (2016). Finansal okuryazarlık düzeyinin belirlenmesi: Üniversite öğrencileri üzerine bir araştırma. Kara Harp Okulu Bilim Dergisi, 2 (26), 1-37.

Demirkol Ö. F., ve Erduru İ., (2017). Üniversite öğrencilerinin finansal Okuryazarlık düzeylerinin tespitine yönelik bir araştırma: Harran üniversitesi örneği. İşletme ve İktisat Çalışmaları Dergisi, 5(4), 12-26.

Er Ç. ve Çetintaş M., (2018). İşçilerde finansal okuryazarlık: finansal bilgi, tutum ve davranış eksenli bir araştırma. Mersin Üniversitesi Sosyal Bilimler Enstitüsü, 1 (2), 61-71.

Er, F., Temizel, F., Özdemir, A. ve Sönmez, H., (2014). lisans eğitim programlarının finansal okuryazarlık düzeyine etkisinin araştırılması: Türkiye örneği. Anadolu Üniversitesi Sosyal Bilimler Dergisi, 14(4), 113-126.

Holzmann, R. (2010) Bringing financial literacy and education to lowand middle in come countries :the need to review, adjust and extend current wisdom, World Bank Social Protection Discussion Paper (No 56501), Washington DC: World Bank Group.

Kılıç Y., Ata H., ve Seyrek İ., (2015). Finansal okuryazarlık: Üniversite öğrencilerine yönelik bir araştırma. Muhasebe ve Finansman Dergisi, 1(66), 129-150. 
Şamiloğlu F., Kahraman Y.E. ve Bağc1 H., (2016). Finansal okuryazarlık araştırması: Erciyes üniversitesi öğrencileri üzerinde bir uygulama. Uluslararası Yönetim İktisat ve İşletme Dergisi, ICAFR 16 Özel Sayis1, 308-318.

Saraç, E., (2014). Finansal okuryazarlık ve dumlupınar üniversitesi öğrencilerinin finansal okuryazarlı düzeylerinin ölçülmesi üzerine bir araştırma. Yayınlanmış Yüksek Lisans Tezi, Dumlupınar Üniversitesi Sosyal Bilimler Enstitüsü, Kütahya.

Sarıül H., (2015). Finansal okuryazarlık tutum ve davranış ölçeği: Geliştirme, geçerlik ve güvenirlik. Yönetim ve Ekonomi Araştırmaları Dergisi, 13 (1), 200-218.

Tuna G., ve Ulu M.O., (2016). Üniversite öğrencilerinin finansal okuryazarlık düzeylerini etkileyen faktörlerin belirlenmesi: İşletme bölümü öğrencileri üzerine bir araştırma. Uluslararası Yönetim İktisat ve İsletme Dergisi, ICAFR 16 Özel Sayısı, 128-141.

\section{Kaynakça Bilgisi / Citation Information}

Gümüş, U.T. ve Pailer, K. M. (2019). Öğrencilerin finans dersialma durumunun finansal okur yazarlık seviyesine etkisi: Bir Nazilli örneği. OPUS-Uluslararası Toplum Araştırmaları Dergisi, 11(18), 1495-1516. DOI: 10.26466/opus.553171 